\title{
Penerapan Tepid Water Sponge Terhadap Penurunan Suhu Tubuh Pada Anak Usia 1 - 5 Tahun: Literature Review
}

\author{
Arif Bagus Susetyo ${ }^{1 *}$, Siti Rofiqoh ${ }^{2}$, Aida Rusmariana ${ }^{3}$ \\ 1,2,3Program Studi Diploma Tiga Keperawatan, Universitas Muhammadiyah Pekajangan \\ Pekalongan, Indonesia \\ *email: arifbagus656@gmail.com
}

\begin{abstract}
One of the non-pharmacological therapies to reduce body temperature in children aged 1-5 years is the tepid water sponge. This paper aims to describe the therapy in reducing kid's temperature. It is a literature review with three articles taken from Google-scholar. They were focused on tepid water sponge and fever as the keywords. To be known, all of them were full-text, published in 2016-2019. The result showed body temperature has reduced into $37,38^{\circ} \mathrm{C}$ from $38,55^{\circ} \mathrm{C}$ afther applying the therapy. Therefore, it could be concluded the therapy works well in reducing kid's temperature. Thus, it is highly recommended for nursing staff to apply the therapy on the children aged 1-5 years.
\end{abstract}

Keywords: fever, tepid water sponge

\begin{abstract}
Abstrak
Salah satu terapi non farmakologi untuk menurunkan suhu tuhuh pada anak usia 1-5 tahun adalah tepid water sponge. Penelitian ini bertujuan untuk menggambarkan penerapan Tepid Water Sponge terhadap penurunan suhu tubuh pada anak usia 1-5 tahun. Desain karya tulis ilmiah berupa literature review dengan jumlah tiga artikel yang diambil dari laman jurnal google scolar dengan kata kunci "tepid water sponge" dan "demam" berupa artikel fulltex, terbit tahun 2016-2019. Hasil analisa dari ke 3 artikel menunjukan nilai rata - rata suhu tubuh sebelum dilakukan tindakan tepid water sponge $38,55^{\circ} \mathrm{C}$ dan setelah dilakukan tindakan tepid water sponge $37,38^{\circ} \mathrm{C}$. Kesimpulannya adalah tepid water sponge dapat menurunkan suhu tubuh anak usia 1 - 5 tahun. Saran bagi pelayanan kesehatan hendaknya menerapkan teknik tepid water sponge untuk menurunkan suhu tubuh usia $1-5$ tahun.
\end{abstract}

Kata kunci: demam, tepid water sponge

\section{Pendahuluan}

Demam adalah suatu keadaan dimana suhu tubuh lebih tinggi dari biasanya atau suhu tubuh diatas normal, umumnya suhu tubuh terjadi ketika anak sedang mengalami gangguan kesehatan, umumnya suhu tubuh normal berkisar $36^{\circ} \mathrm{C}-37,5^{\circ} \mathrm{C}$, jadi anak demam setelah suhu tubuh berada diatas $37,5^{\circ} \mathrm{C}$, demam bisa dialami siapa saja terutama anak yang daya tahan tubuhnya rendah, demam disebabkan karena adanya infeksi virus yang menyerang tubuh, gejala yang sering muncul biasanya batuk pilek radang tenggorokan dan pneumoni, dampak berbahaya yang disebabkan oleh demam dapat terjadinya kejang dan kerusakan otak (Djuwariah \& Yulistiani 2011).

Badan kesehatan dunia (WHO) memperkirakan jumlah kasus demam diseluruh dunia mencapai 16-33 juta dengan 500-600 ribu kematian setiap tahunnya (Setyowati, 2013). Data kunjungan ke fasilitas kesehatan pediatrik di Brazil terdapat sekitar 19\% 


\section{Prosiding Seminar Nasional Kesehatan Lembaga Penelitian dan Pengabdian Masyarakat Universitas Muhammadiyah Pekajangan Pekalongan}

sampai $30 \%$ anak diperiksa karena menderita demam. Di Indonesia penderita demam sebanyak 465 (91.0\%) dari 511 ibu yang memakai perabaan untuk menilai demam pada anak mereka sedangkan sisanya 23.1 saja menggunakan thermometer. Data dinas kesehatan Provinsi Lampung tahun 2013 menyebutkan bahwa demam dengan klasifikasi 1.837 anak pada usia 1-4 tahun, 1.192 anak pada usia 5-9 tahun (Setyowati, 2013).

Menurut Suntari, (2019) Dampak demam tinggi dapat menyebabkan alkalosis respiratorik, asidosis metabolic, kerusakan hati, kelainan EKG, dan berkurangnya aliran darah otak, dampak lain dari demam tinggi yang tidak ditangani maka akan dapat menyebabkan kerusakan hiperpireksia yang akan menyebakan kerusakan otot hipereksia yang dapat menyebabkan syok, epilepsy, retardasi mental atau ketidakmampuan belajar.

Penanganan demam dibagi menjadi dua yaitu tindakan farmakologis dan non farmakologis, farmakologis adalah tindakan pemberian obat untuk menurunkan demam atau sering disebut antipiretik. menurut Sodikin (2012), antipiretik memberikan kesembuhan yang bersifat simtomis, tetapi antipiretik tidak dapat mengubah perjalanan penyakit infeksi biasa pada anak normal. non-farmakologis adalah tindakan penurunan demam dengan menggunakan terapi fisik seperti menempatkan anak di ruang bersuhu dan bersikulasi baik, mengganti pakaian dengan pakaian yang tipis dan mudah menyerap keringat dan memberikan kompres (Hamid, 2011). kompres adalah suatu metode untuk menurunkan demam, salah satu metode kompres yang sering dilakukan adalah pemberian tepid water sponge (kompres hangat). tepid water sponge adalah tindakan untuk menurunkan suhu tubuh dengan cara merendam anak dengan air hangat bisa juga mengelap sekujur tubuh dengan waslap dan mengompres di bagian tubuh tertentu yang memiliki pembuluh darah besar (Bardu, 2014).

\section{Literature Review}

Demam adalah suatu kondisi suhu tubuh lebih tinggi dari biasanya atau suhu tubuh diatas $37,5^{\circ} \mathrm{C}$, umumnya demam terjadi karena anak mengalami gangguan kesehatan suhu tubuh normal biasanya $36^{\circ} \mathrm{C}-37,5^{\circ} \mathrm{C}$. Jadi anak dapat dikatakan demam ketika suhu tubuh lebih dari $37,5^{\circ} \mathrm{C}$. Demam merupakan bentuk mekanisme pertahanan tubuh dari serangan penyakit (Djuwariah \& Yulistiani 2011).

Tepid water sponge adalah suatu prosedur untuk meningkatkan kontrol kehilangan panas tubuh melalui evaporasi dan konduksi, yang diterapkan pada pasien demam (Hidayati, 2014). Menurut Bardu (2014) tepid water sponge merupakan tindakan untuk menurunkan suhu tubuh saat demam dengan cara merendam anak ke air hangat atau mengelap sukujur tubuh anak dengan waslap dengan mengompres dibagian tubuh tertentu yang memiliki pembuluh darah besar.

Tujuan dilakukan tepid water sponge adalah untuk menurunkan suhu tubuh pada anak penderita demam (Hidayati, 2014). tepid water sponge dapat memberikan rasa aman, nyaman dan mengurangi nyeri yang diakibatkan oleh penyakit yang disebabkan oleh demam (Hamid, 2011). 


\section{Prosiding Seminar Nasional Kesehatan Lembaga Penelitian dan Pengabdian Masyarakat Universitas Muhammadiyah Pekajangan Pekalongan

\section{Metode}

Metode pengumpulan data dengan pencarian artikel ilmiah menggunakan laman web google scholar dengan mencari artikel ilmiah dengan kata kunci tepid water sponge, Artikel ditemukan sebanyak 670 artikel kemudian mengategorikan pada anak usia 1-5 tahun, ditemukan 77 artikel. Kemudian mengkategorikan tahun terbit 5 tahun terakhir ditemukan 7 artikel dan diseleksi artikel menggunakan alat ukur yang sama dan jenis data yang sama yaitu numerik, maka ditemukan 3 artikel yang sesuai dengan topik karya tulis ilmiah.

\section{Hasil dan Pembahasan}

Hasil

Berdasarkan 3 artikel yang di review hanya 2 artikel yang menampilkan karakteristik umur dan jenis kelamin. Ke 2 artikel tersebut yaitu artikel dari penulis NLP Yunianti Suntari. Putu Susy Natha Astini. \& Ni Made Desi Sugiani dan dari penulis Anggreini Beti Dwi Lestari. Bambang Sarwono. \& Adi Isworo. Pada artikel 1 yang ditulis Lina Novikasari. Edita Revine Siahaan. \& Maryustiana. Tidak menampilkan karakteristik umur dan jenis kelamin. Karakteristik demografi menurut umur dan jenis kelamin dari 2 artikel tersebut dengan total 60 responden dijelaskan di tabel 1 dan 2

Tabel 4.1 Karatkteristik responden berdasarkan umur $(n=60)$

\begin{tabular}{ccccccccc}
\hline Karakteristik & Artikel 1 & Artikel 2 $(\mathrm{n}=30)$ & \multicolumn{2}{c}{$\begin{array}{c}\text { Artikel 3 } \\
(\mathrm{n}=30)\end{array}$} & \multicolumn{2}{c}{$\begin{array}{c}\text { Total } \\
(\mathrm{n}=60)\end{array}$} \\
Umur & $\mathrm{F}$ & $\%$ & $\mathrm{~F}$ & $\%$ & $\mathrm{f}$ & $\%$ & $\mathrm{~F}$ & $\%$ \\
\hline $1-2$ tahun & - & - & 17 & 56,67 & 6 & 20,0 & 23 & 38,3 \\
\hline $2-3$ tahun & - & - & 5 & 16,67 & 6 & 20,0 & 11 & 18,3 \\
\hline $3-4$ tahun & - & - & 3 & 9 & 6 & 20,0 & 9 & 15 \\
\hline $4-5$ tahun & - & - & 5 & 16,67 & 12 & 40,0 & 17 & 28,4 \\
\hline Total & & & 30 & 100 & 30 & 100 & 60 & 100 \\
\hline
\end{tabular}

Berdasarkan tabel 4.1 pada artikel 1 tidak menampilkan distribusi frekuensi karakteristik responden berdasarkan umur. Pada artikel 2 terdapat responden usia anak 1-2 tahun $56,67 \%$, usia $2-3$ tahun $16,67 \%$, usia 3-4 tahun $9 \%$ usia $4-5$ tahun $16,67 \%$. Sedangkan pada artikel 3 terdapat responden usia anak 1-2 tahun $20,0 \%$, usia 2-3 tahun 20,0\%, usia 3-4 tahun 20,0\%, usia 4-5 tahun 40,0\%. Dari 60 responden yang diberikan perawatan tepid water sponge terbanyak usia 1-2 tahun sejumlah $38,3 \%$.

Tabel 4.2 karakteristik responden berdasarkan jenis kelamin $(n=60)$

\begin{tabular}{ccccccccc}
\hline Karakteristik & Artikel 1 & \multicolumn{2}{c}{$\begin{array}{c}\text { Artikel 2 } \\
(\mathrm{n}=30)\end{array}$} & Artikel 3 $(\mathrm{n}=30)$ & \multicolumn{2}{c}{$\begin{array}{c}\text { Total } \\
(\mathrm{n}=60)\end{array}$} \\
\hline Jenis kelamin & $\mathrm{F}$ & $\%$ & $\mathrm{f}$ & $\%$ & $\mathrm{f}$ & $\%$ & $\mathrm{f}$ & $\%$ \\
\hline Laki laki & - & - & 21 & 70 & 17 & 56,7 & 38 & 63,3 \\
\hline Perempuan & - & - & 9 & 30 & 13 & 44,2 & 22 & 36,7 \\
\hline Total & - & - & 30 & 100 & 30 & 100 & 60 & 100 \\
\hline
\end{tabular}




\section{Prosiding Seminar Nasional Kesehatan Lembaga Penelitian dan Pengabdian Masyarakat Universitas Muhammadiyah Pekajangan Pekalongan}

Berdasarkan tabel 4.2 disebutkan bahwa pada artikel 1 tidak menampilkan karakteristik responden berdasarkan jenis kelamin. Pada artikel 1 jumlah responden pada jenis kelamin laki-laki 70\%, jenis kelamin perempuan $30 \%$. Sedangkan artikel 3 terdapat jumlah responden jenis kelamin laki-laki $56,7 \%$, jenis kelamin perempuan $44,2 \%$. Berdasarkan ke 3 artikel yang dilakukan perawatan tepid water sponge jenis kelamin laki-laki sejumlah $38(63,3 \%)$ dan jenis kelamin perempuan sejumlah 22 $(36,7 \%)$.

Tabel 4.3 rata-rata suhu tubuh sebelum dan sesudah tepid water sponge $(n=100)$

\begin{tabular}{ccc}
\hline \multirow{2}{*}{ Artikel } & \multicolumn{2}{c}{ Nilai rata rata } \\
\cline { 2 - 3 } & $\begin{array}{c}\text { Sebelum dilakukan tepid water } \\
\text { sponge }\left({ }^{\circ} \mathrm{C}\right)\end{array}$ & $\begin{array}{c}\text { setelah dilakukan tepid water } \\
\text { sponge }\left({ }^{\circ} \mathrm{C}\right)\end{array}$ \\
\hline $\begin{array}{c}\text { Artikel 1 } \\
\mathrm{n}=40\end{array}$ & 38,615 & 37,405 \\
\hline $\begin{array}{c}\text { Artikel 2 } \\
\mathrm{n}=30\end{array}$ & 38,61 & 38,38 \\
\hline $\begin{array}{c}\text { Artikel 3 } \\
\mathrm{n}=30\end{array}$ & 38,417 & 36,503 \\
\hline Total & 38,55 & 37,38 \\
$\mathbf{n}=\mathbf{1 0 0}$ & &
\end{tabular}

Berdasarkan tabel 4.3 disebutkan bahwa nilai rata-rata suhu tubuh pada anak sebelum dilakukan tepid water sponge artikel 1 sebesar $38,615^{\circ} \mathrm{C}$ menurun menjadi $37,405^{\circ} \mathrm{C}$ setelah dilakukan tepid water sponge, pada artikel 2 sebelum dilakukan tepid water sponge $38,61^{\circ} \mathrm{C}$ menurun menjadi $38,38^{\circ} \mathrm{C}$ setelah dilakukan tepid water sponge, dan pada artikel 3 sebelum dilakukan tepid water sponge $38,417^{\circ} \mathrm{C}$ menurun menjadi $36,503^{\circ} \mathrm{C}$ setelah dilakukan tepid water sponge. Nilai rata-rata dari ke 3 artikel sebelum dilakukan tepid water sponge $38,55^{\circ} \mathrm{C}$ dan setelah dilakukan tepid water sponge menurun menjadi $37,38^{\circ} \mathrm{C}$.

\section{Pembahasan}

Berdasarkan ke 3 artikel ilmiah yang dilakukan literature riview pada artikel 1 tidak terdapat karatkteristik responden berdasarkan umur dan jenis kelamin, pada artikel 2 dan 3 terdapat karatkteristik responden berdasarkan umur dan jenis kelamin. Berdasarkan tabel 1 . dari total responden 60 sebagian besar yaitu sejumlah 23 $\left(38,3^{\circ} \mathrm{C}\right)$ usia $1-2$ tahun. Pada usia ini belum terjadi kematangan mekanisme pengturan suhu tubuh yang menyebabkan tubuh tidak dapat menjaga keseimbangan antara produksi panas dan pengeluaran panas. Suhu tubuh pada anak yang mengalami demam dipengaruhi proses penyakit yang terjadi pada anak (Potter \& Perry, 2010).

Berdasarkan dari ke 3 artikel pada tabel 3. bahwa nilai rata-rata sebelum dilakukan tindakan tepid water sponge sebesar $38,55^{\circ} \mathrm{C}$, dan nilai rata-rata sesudah dilakukan tindakan tepid water sponge sebesar $37,38^{\circ} \mathrm{C}$

Perawatan tepid water sponge merupakan perawatan yang efektif untuk menurunkan panas pada saat demam yang dilakukan dengan mengompres pada lima titik (leher, 2 ketiak, 2 pangkal paha) ditambah menyeka bagian perut dan dada atau diseluruh badan dengan kain dibasahi air hangat (Kusnanto, 2008). Tepid water 


\section{Prosiding Seminar Nasional Kesehatan Lembaga Penelitian dan Pengabdian Masyarakat Universitas Muhammadiyah Pekajangan Pekalongan}

sponge bekerja dengan cara vasodilatasi (melebarnya) pembuluh darah perifer diseluruh tubuh sehingga evaporasi panas dari stimulasi hipotalamus. Terjadinya vasodilatasi ini menyebabkan pembunagan/kehilangan energy/panas melalui kulit meningkat (berkeringat), diharapkan akan terjadi penurunan suhu tubuh sehingga mencapai keadaan normal kembali (Mailing, Haryani, \& Arif, 2012).

Tepid water sponge berpengaruh terhadap penurunan suhu tubuh karena kompres blok langsung dilakukan dibeberapa tempat yang memiliki pembuluh darah besar, sehingga mengakibatkan peningkatan sirkulasi serta peningkatan kapiler. Pemberian tepid water sponge dapat menurunkan suhu tubuh melalui proses penguapan dan dapat memperlancar sirkulasi darah, sehingga darah akan mengalir dari organ dalam kepermukaan tubuh dengan membawa panas. Kulit memiliki banyak pembuluh darah, terutama tangan, kaki, dan telinga. Aliran darah melalui kulit mencapai 30\% dari darah yang dipompakan jantung. Kemudian panas berpindah dari darah melalui dinding pembuluh darah kepermukaan kulit dan hilang ke lingkungan sehingga terjadi penurunan suhu tubuh (Potter \& Perry, 2011).

Berdasarkan ke 3 artikel tersebut menunjukkan ada pengaruh perawatan tepid water sponge terhadap penurunan suhu tubuh pada anak usia 1-5 tahun. Hal ini menunjukkan bahwa perawatan tepid water sponge efektif untuk menurunkan suhu tubuh anak usia 1-5 tahun.

\section{Kesimpulan}

Dari ketiga artikel yang membahas mengenai pemberian teknik tepid water sponge dapat menurunkan suhu tubuh pada anak usia $1-5$ tahun, dapat disimpulkan bahwa tepid water sponge terbukti efektif dapat menurunkan suhu tubuh anak usia 1 - 5 tahun. Pada Penelitian 1 nilai rata-rata sebelum tindakan yaitu $38,615^{\circ} \mathrm{C}$, sesudah tindakan $37,405^{\circ} \mathrm{C}$, penelitian 2 nilai rata-rata sebelum tindakan $38,61^{\circ} \mathrm{C}$, sesudah tindakan $38,38^{\circ} \mathrm{C}$ dan penelitian 3 nilai rata-rata suhu tubuh sebelum tindakan $38,417^{\circ} \mathrm{C}$ dan sesudah tindakan $36,503^{\circ} \mathrm{C}$. Nilai rata-rata dari ketiga artikel sebelum tindakan tepid water sponge yaitu $38,55^{\circ} \mathrm{C}$ dan setelah diberikan tindakan tepid water sponge yaitu $37,38^{\circ} \mathrm{C}$ dari hasil ketiga artikel tersebut dapat disimpulkan bahwa tepid water sponge terbukti efektif untuk menurunkan suhu tubuh anak usia $1-5$ tahun.

\section{Referensi}

[1] Bardu, T.Y. (2014). Perbandingan Efektifitas Tepid Water Sponge Dan Plaster Kompres Dalam Menurunkan Suhu Tubuh Pada Anak Usia Balita Yang Mengalami Demam di Puskesmas Salaman 1 Kabupaten Magelang.

[2] Djuwariyah, Sodikin, \& Yulistiani, M. (2011). Efektifitas Penurunan Suhu Tubuh Menggunakan Kompres Air Hangat dan Kompres plaster pada anak dengan Demamdiruang kanthil Rumah Sakit Umum Daerah Banyumas.

[3] Hamid, M. A. (2011). Keefektifan Kompres Tepid Sponge Yang Dilakukan Ibu Dalam Menurunkan Demam Pada Anak: Randomized Control Trial Di Puskesmas Mumbulari Kabupaten Jember: (Tesis, Universitas Sebelas Maret).

[4] Hidayati, R. (2014) Praktik Laboratorium Keperawatan Jilid 1. Jakarta:Erlangga 


\section{Prosiding Seminar Nasional Kesehatan Lembaga Penelitian dan Pengabdian Masyarakat Universitas Muhammadiyah Pekajangan Pekalongan

[5] Setyowati, L. (2013). Hubungan Tingkat Pengetahuan Orang Tua dengan Penanganan Demam pada Anak Balita di Kampung Bakalan Kadipiro Banjarsari Surakarta. Skripsi, STIKES PKU Muhammadiyah.

[6] Suntari, (2019). Jurnal Kesehatan "Pengaturan Suhu Tubuh dengan Metod Tepid. Water Sponge dan Kompres Hangat pada Balita Demam"

[7] Sodikin. (2012). Prinsip Perawatan Metode Kanguru pada Anak. Yogyakarta: Pustaka Belajar.

[8] Lestari, A.B.D., Sarwono, B., Isworo, A (2019). Efektifitas water tepid sponge suhu $37^{\circ} \mathrm{C}$ dan kompres hangat suhu $37^{\circ} \mathrm{C}$ terhadap penurunan suhu tubuh pada anak dengan hipertermia. Jurnal keperawatan mersi, volume VIII, no 2, 